\title{
Why Are Written Communication Skills Important For Business Students?
}

\author{
Susan J. Kowalewski \\ Professor, Business Department \\ D’Youville College, 320 Porter Avenue, \\ Buffalo, New York, USA 14201 \\ Magdalene E. Halasz \\ Clinical Assistant Professor, Business Department \\ D’Youville College, 320 Porter Avenue, \\ Buffalo, New York, USA 14201
}

\begin{abstract}
Notwithstanding the availability of business writing instruction in academia, employers continue to voice their concerns about the significant gap between their expectations for employees' writing skills and the actual skills employees possess (Lentz, 2013). Organizations are reporting lower levels than "meet expectations" related to employees' written communication skills at the time an employee is hired (Suvedi, M., Ghimire, R.P., \& Millenbach, K.F., 2016). Consequently, employers spend a considerable amount on remedial training to address the poor writing skills among their employees (White, A.V., 2015). Employers expect that written communication skills are taught in college. Data demonstrates, however, that this is not occurring or at least not to the level of competence that employers are seeking (Carnes, L., Awang, F., \& Smith, H., 2015). Colleges and universities need to evaluate their curriculum and outcomes; integrating new initiatives into the curricula and programs to improve the written communication skills of their students.
\end{abstract}

Keywords: written communication skills, business students, employers

\section{INTRODUCTION}

According to Rentz and Lentz (2018), "timely and clear transfer of information is critical to businesses, now more than ever" ( $p$ 22). Written communication in organizations has evolved from letters and memos to email, Tweets, and Web pages. A question to be asked is, "Are Business students graduating from colleges and universities with the written communications skills required to be successful in today's organizations?" Institutions of higher education have a responsibility in preparing students to have the proficiency to think critically so that they can be effective citizens but also for preparation in entering the workforce. Educators and employers alike continue to voice their concerns about the significant gap between their expectations for individuals' writing skills and the actual skills they possess (Lentz, 2013). The skills employees need to be successful in the workplace are different than 20 years ago and they will be different 10 years from today. Fast changing technologies necessitate strong communication skills.

According to White (2015),

Over $70 \%$ of employers rank writing skills as paramount in the hiring process...

With the U.S. government also valuing written communication so highly that it implemented the "Plain Writing Act of 2010," which requires federal agencies to use writing that is "clear, concise, well-organized, and follows other best practices appropriate to the subject or field and intended audience (p. 73). 
Proficient writing skills increase the marketability of new college graduates in the workplace. Individuals use communication skills every day. Poorly written letters, emails, resumes, and other correspondence effect an organizations and its employee's reputation. White (2015) supports the importance of communication as to an organization's ability to meet goals and objectives with "professionalism, accuracy, clarity and brevity" (p 76). Understanding the instances where a familiar tone versus formal tone when communicating in writing. Responding to a customer in a tone that is too casual could cost the organizations thousands of dollars, and potential customer's future business; and employees' could lose their job.

It is expected of institutions of higher education to graduate individuals who can enter the workforce with specific proficiencies. Written communication skills are one of these skillsets. Students are graduating without adequate writing skills at a time when the high cost and utility of a college education is under scrutiny (Sigmar \& Hynes, 2011). This paper is specific to business students' written communication skills, interventions initiated for improvement, and expected outcomes of a research study being conducted at a private institution in the Northeastern United States (U.S.).

\section{LITERATURE REVIEW}

At their inception Business schools were trade schools that were criticized for the lack of academic focus. As a consequence, attention to scientific research was called for Business schools aspiring to become institutions of higher education. A current concern is, however, that this movement has shifted too far toward academic emphasis, with not enough attention to the practical needs of organizations hiring graduates (McMurray, Dutton, McQuaid, and Richard, 2016). The challenge of business education is to find the right balance between theory and practical education. It is a dilemma constantly confronted by business schools. It is imperative that colleges and universities meet the demands of employers regarding educational expectations. Written communication skills have been reported in various studies as integral for business graduates (Jones, Baldi, Phillips, and Waikar, 2016). When communication methods change as rapidly as they do today, business schools have the responsibility to teach the skills necessary to fulfil this need. The trend that students are entering institutions of higher education with poor writing skills can no longer be ignored. Organizations have the expectation that colleges and universities will teach the literacy skills necessary for the job market. Business writing tends to require a crisp, concise tone and style, conveying authority and confidence (White, 2015).

The labor market continues to be competitive, especially for highly qualified, competent employees (McMurray, Dutton, McQuaid, Richard, 2015). Soft skills have consistently been ranked highest in recruiter preferences by organizational surveys (Jones, Baldi, Phillips, \& Waikar, 2016). Lower-order communication skills such as texting, Instagram, Twitter have a negative impact on writing skills. According to Nisen (2015), for many companies, Google among them, grades are not a marker of future success in a job.

There are many ways faculty can have an impact on a student's career opportunities. In business education, theory is the basis of most courses, practical experience is not emphasized. Internships, guest speakers, opportunities to travel internationally to learn different approaches to business can equip a student with practical experience prior to entering the workforce. There has been significant research as to the impact of grades in the hiring of new employees. Grade inflation continues to pose a problem in institutions of higher education. According to Kostal, Kuncel, and Sackett (2015), "By providing students with high grades, schools provide tacit endorsement of their potential as job candidates. When these 
endorsements are not accurate, companies may be harmed (p. 11)." Development of faculty in student grading and evaluation can provide a solid basis of expectations of student performance for an entire academic department. Developing rubrics that are used for grading research papers, presentations, essays, case studies, and other assignments can provide a foundation for student writing improvement while pursuing their degree programs. Over the past 50 years there has been a "consistent increase in the average grade point average (GPA) of college students at 4-year institutions;... grading leniency and the frequency of nontraditional letter grades are explanations" (Kostal et al, p. 11 \&18). For employers who use GPA minimums during selection for interviews, organizations should take grade inflation into account. Providing guidelines, support, and departmental rubrics for faculty, especially adjuncts, could mitigate grade inflation and provide employers with a more realistic guidepost for hiring.

The idea of higher education meeting the requirements of employers has been a topic of many a conversation between business and academia. One area that organizations are reporting lower levels than "meet expectations" is related to employees' written communication skills at the time of hiring (Suvedi, M., Ghimire, R.P., \& Millenbach, K.F., 2016). Instructors often empathize in faculty meetings and offices about the poor writing skills of students who are entering college and universities (Sigmar \& Hynes, 2011). While most undergraduate programs have required or recommended elective courses in Business Communications with the objective of teaching business writing skills, "business communication courses alone do not produce competent business communicators" (Sigmar \& Hynes, 2011, p 135). It's not only instruction in how to write business letters, emails, or memos that are objectives of business communication courses. Instructors also need to motivate, providing additional opportunities for practice and effective feedback.

According to Hora (2017),

"employers reported if they had to imagine a composite "ideal" employee, they envisioned a hard-working individual with appropriate technical training (knowledge as well as the ability to apply technical information), solid problem-solving skills, and the abilities to communicate well, work in teams, and to continually learn new things"(p.4)

Hora notes the importance of curriculum advisory boards with representatives from local businesses and organizations to provide information and guidance related to the types of current and future tasks and skills necessary for success in the workplace. Employers expect that writing communication skills are taught in college. Data demonstrates that employers spend a considerable amount, an estimated 2.9 billion per year on remedial training to address the poor writing skills of their employees (White, 2015). Colleges and universities need to evaluate their curriculum and outcomes, integrating new initiatives into the curricula and programs to improve the written communication skills of their students.

Business programs that are accredited through organizations such as The Association to Advance Collegiate Schools of Business (AACSB) or International Accreditation Council for Business Education (IACBE) have defined competencies to assess student learning. These competencies determine what student learning outcomes will be measured, evaluate the data related to meeting criteria, and implementation effective teaching practices that are expected to improve student learning (AACSB Website, IACBE Website).

According to Rentz and Lentz (2018), having proficiency in writing skills can help individuals appear more professional, credible, adept and skillful than an associate who writes with substantial spelling and grammatical errors. There are jobs that require excellent 
communication skills such as journalism, marketing, or advertising. Yet, today the majority of jobs require a significant amount of written communication involved in day to day responsibilities. Emails, notes, letters, texts and Tweets have had a huge impact on the amount of time individuals spend writing at work and in their personal lives. Whether responding to customers with email, sending a text message to a colleague, writing to a supervisor or developing an organizations' web page or newsletter, writing skills can boost or derail a career. Writing skills make a difference in how an individual is assessed. Individuals with good writing skills are generally seen as more credible and professional, as well as better educated. Receiving an email filed with spelling and grammatical errors from a coworker begs a question. At best, was the writer negligent in not proofreading a message or use spell check? At worst, is the writer less intelligent and capable? Better writers many times earn higher grades, are perceived as more proficient and intellectual than their colleagues.

In management, communication is critical in every area of an organization's operations from Human Resources to Customer Service. Every day in organizations, employees request information, respond to emails, and write business letters. In the workplace proofreading is instrumental from emails to company memos. As a manager, receiving or reviewing other employees' written correspondence can be frustrating, disenchanting, and disturbing. It is important for organizations to communicate to perspective employees what skills and traits are required for a position. Having these areas evaluated in appraisals and reviews signifies the importance of these skills. According to Bell and Quddus (2006), "a written document plagued with language errors (noise) might completely distort a message, resulting in an altered effect or failed communication...and the reader's feedback to the writer is normally of non-response (p. 2)." The goal of institutions of higher education should be to teach students that reducing errors in their writing would result in improved communication with fewer errors and greater understanding by the reader.

Context and tone are just as important as grammar. While obvious mistakes are egregious, such as using "their" and "they're" incorrectly, smaller errors, like confusing "who" and "whom" are less important. There are over 55 countries where English is the official language worldwide (5minuteenglish.com website). English has developed into the "global language" signifying its importance in verbal and written communication in management (Arputhamalar, A., and Kannan, S, P., 2017). Professional behavior as it relates to written communication is pivotal. A recommendation of Jones (et al) is that "colleges can institutionalize a code of conduct (e.g., no cell phones allowed to ring in class, no texting in class, tardiness not allowed, students must speak one at a time) that raises awareness of what it means to engage in professional behavior (p. 427).

\section{METHOD}

The research study is taking place at a private college in Western New York with over 3,000 undergraduate and graduate students. For the purposes of this paper, the importance of written communication is addressed in the academic year 2017-2018. It is the first year of collecting student writing samples, evaluating the data, and implementing interventions. The study is a longitudinal study that will assess writing skills of Business Management and Accounting students during their programs of study.

Business Management and Accounting students will provide writing samples for assessment in the four required classes in years one, two, three, and four of their programs. The writing samples will be reviewed independently by the researchers of this study using a rubric developed by ReadWriteThing (Appendix A). Writing samples are being collected in Principles 
of Management (MGT 305), Business Communications (MGT 304), and Organizational Behavior (MGT 401). Business Management students' final writing sample will be collected in the class, Management Policy and Strategy (MGT 412). Accounting students final writing sample will be collected in Advanced Accounting (ACC 404). A core requirement for the college is for students to complete two Writing Intensive (WIP) courses during their program of study. Students in the Business Management and Accounting programs are required to complete two Writing Intensive (WIP) courses offered within their perspective programs: Business Communications and Organizational Behavior. These two classes will incorporate new interventions with the goal of improving student written communication skills. To date writing samples for Year One have been collected in the Principles in Management course and will be reviewed.

Content areas reviewed in evaluating student writing in the rubric include: Content/Ideas, Organization, Vocabulary/Word Choice, Voice, Sentence Fluency, and Conventions. The rubric evaluates students numerically from one to six; with one "Does Not Meet the Standard", two is Partially Meets Standard", three is "Does Not Fully Meet Standard", four is "Meets standard", five as "More than Meets Standard", and six "Exceeds the Standard". The researchers reviewed the writing samples independently with no identifiers related to student sex, age, or prior writing classes completed noted. Data analysis of Year One is currently underway. The research project was reviewed and approved by the institutions Review Board prior to beginning the research.

\section{DESCRIPTION OF DATA / RESULTS}

The first year results included data from 10 writing samples. Initial analysis for Year One notes that the area of greatest concern is "Conventions" (agreement levels of speech, errors in mechanics, spelling); followed by "Voice" (writer's point of voice/view). Organization", "Vocabulary/Word Choice", and "Sentence Fluency" (run-ons or fragments, variety of sentence structure) were equal in the number of errors. The area where student writing was rated as strongest was "Content/Ideas". Specific areas from initial review of writing samples include deficiencies in writing complicated sentences, punctuation, improper subject-verb agreement, incorrect or poorly chosen word usage and spelling mistakes, and ineffective editing.

Course materials are being updated to support areas that students are especially lacking. This includes assignments reviewing homophones (you are, your, you're), word choice usage errors (farther vs. further, prejudice vs. prejudiced), using transition words and phrases, drafting and peer review. Instructional videos (APA) are included in the required Writing Intensive courses.

\section{DISCUSSION}

Initial assessment of the data supports the need for increased interventions and support related to student writing skills. Although perfect grammar and sentence structure do not indicate an understanding of a topic area, there is an increase in the desired effect (better written business letters, email, memos, business plans) when students graduate with a proficiency in written communication skills.

A significant challenge relates to continuity. What is taught in one course should be reinforced in each following course. The current practice of each course being a "silo" does not facilitate student learning. A baseline set of expectations, regardless of who is teaching the class should be instituted to ensure students maintain and build on proficiencies throughout their programs of study. This will provide students with an understanding of the priority given to increasing their proficiency in writing. It's not unusual to hear comments from faculty such as "I teach accounting. I grade students related to accounting assignments; not how they write". 
It can be challenging to provide faculty with the freedom to design assignments to assess student learning while meeting the needs of the students and department. Many times, business faculty members do not think they have the skills or proficiency to evaluate students writing skills because they do not possess the necessary skillset as to grammar, punctuation, or sentence structure. To decrease "silos" in the education of students, business departments will need to develop guidelines, rubrics, and to provide professional development programs to ensure everyone is working toward the goal of graduating students with a proficiency in written communication.

The idea of lifelong learning has long been supported by researchers and employers (Hora, 2017). Higher education should be inculcating the love of lifelong learning in students prior to entering the workplace. With technological change occurring so quickly, individuals need to continue their learning through completing additional degrees, certificates, or independent studies. "One AT\&T executive put it bluntly, saying that people who are not spending five to 10 hours a week learning new skills "will obsolete themselves with the technology (p. 7)." Organizations are requiring their employees to maintain a specific level of qualification and proficiency. Written communication skills in the workplace is a basis of many of these requirements. Many organizations believe that courses related to the humanities are not pertinent to preparing students for the workplace. However, "courses in the arts and humanities are uniquely well-suited to provide training in certain competencies like oral and written communication" (Hora, p 9). In a recent survey reported by Hora (2017) of 41,000 hiring managers globally, only one in five employers were investing in the training and development of their workforce.

Courses related specifically to developing competencies and skill sets that can be utilized in the workplace are imperative. Business communication courses uniquely meet this requirement. These courses routinely teach business letter writing, email professionalism and etiquette, business plans and executive summaries, and oral presentation skills. Employing "real world" assignments in business classes provide students with skills they will utilize every day in the workplace. Incorporating assignments that are as close as possible to what employees experience daily can provide the basis for success. This can be as simple as incorporating an assignment in a business communication class, for example, where the students write a response letter to an irate customer. Skills-based learning is well suited for business classes because so many assignments can be developed for real world scenarios.

\section{LIMITATIONS AND FUTURE RESEARCH}

The study results should not be generalized to any population other than the students sampled at the institution where the study is being conducted. Many students in the MGT 305 course did not satisfy the basic requirement of English composition. One limitation is that the sample size is small. Depending on the entering number of Business students, this number could increase during the course of this study. The study is also being conducted at only one college. This makes it a challenge to generalize results to other institutions, although the data does have the strength of prior research to support applicability. Future research could incorporate the development of a survey for employers and one specifically for students related to learning in the two Writing Intensive classes to obtain information from student and employer views.

Proficiency in written communication is an important skill to have in any career. Future employers look to recruit employees who will work to meet the goals and mission of the organization. Employees who write with "clarity, brevity, accuracy and professionalism" 
(White, p 80) will have greater success, as well as organizations having employees who are more accomplished.

\section{References}

Arputhamalar, A., and Kannan, S, P. (2017). Why Can't Tertiary Learners Write A “Decent” Business Letter? The IUP Journal of English Studies, 12(1), 84-90.

Bell, R.L. and Quddus, M. (2006). Helping Business Students Improve as Writers. Institute of Educational Services Website. ED490807.

Carnes, L., Awang, F., and Smith, H (2015). Assurance of writing in a writing-intensive business Course. Journal of Case Studies in Accreditation and Assessment, 4(2), 1-10.

Hora, M.T. (2017). Beyond the Skills Gap, National Association of Colleges and Employers, NACE Website, February.

International Accreditation Council for Business Education Website. www.iacbe.org

Jones, M., Baldi, C., Philips,, C. and Wakar, A. (2016). The Hard Truth About Soft Skills: What Recruiters Look for in Business Graduates, College Student Journal, 422-428.

Kostal, J. W., Kuncel, N. R., and Sackett, P. R. (2016). Grade Inflation Marches On: Grade Increases from the 1990s to 2000s. Educational Measurement: Issues and Practice. Spring, 35 (1), 11-20.

Lentz, P. (2013). MBA Students' Workplace Writing: Implications for Business Writing Pedagogy and Workplace Practice. Business Communication Quarterly, Sage Publishing.

McMurray, S., Dutton, M., McQuaid, R., and Richard, A. (2016). Employer demands from business graduates. Education + Training, 58 (1), 112-132.

Nisen, M (2015). Do grades matter? Depends if you're asking Google or Goldman Sachs. Retrieved from http://qz.com/382570/goldman-sachs-acturally-google-gps-arent-worthless/

Rentz, K. and Lentz, P. (2018). Business Communication: A ProblemSolving Approach. McGraw Hill Publishers.

Sigmar, L. S. and Hynes. G. E. (2011). Major Difference: An examination of student writing performance by majory and its implications for Business communication. Administrative Issues Journal, Doi: 10.5929/2011.2.1.6, 133-145.

Suvedi, M., Ghimire, R.P., and Millenbah, K.F. (2016). How Prepared are Undergraduates for a Career? North American Colleges and Teachers of Agriculture. 60 (1a) 13-20.

The Association to Advance Collegiate Schools of Business Website. www.AACSB.org White, A. V. (2015). Writing for the Real World: Business Communication for College Students.

Journal of Higher Education Theory and Practice. Vol 15(4), 73-84.

5minuteenglish website. 5minuteenglish.com/english-around-world.html 


\section{APPENDIX (A) \\ RUBRIC}

\begin{tabular}{|c|c|c|c|c|c|c|}
\hline \multicolumn{3}{|l|}{ Rubric for } & & \multicolumn{3}{|l|}{ Student Name } \\
\hline & $\begin{array}{c}\text { Does Not Meet } \\
1\end{array}$ & $\begin{array}{c}\text { Partially Meets } \\
2 \\
\end{array}$ & Does Not Fully Meet 3 & $\begin{array}{c}\text { Meets } \\
4\end{array}$ & $\begin{array}{c}\text { More Than Meets } \\
5\end{array}$ & $\begin{array}{c}\text { Exceeds } \\
6\end{array}$ \\
\hline Content/Ideas & $\begin{array}{l}\text { Writing is extremely } \\
\text { limited in } \\
\text { communicating } \\
\text { knowledge, with no } \\
\text { central theme }\end{array}$ & $\begin{array}{l}\text { Writing is limited in } \\
\text { communicating } \\
\text { knowledge. Length is } \\
\text { not adequate for } \\
\text { development. }\end{array}$ & $\begin{array}{c}\text { Writing does not clearly } \\
\text { communicate knowledge. } \\
\text { The reader is left with } \\
\text { questions. }\end{array}$ & $\begin{array}{c}\text { Writes related, quality } \\
\text { paragraphs, with little or } \\
\text { no details. }\end{array}$ & $\begin{array}{l}\text { Writing is purposeful } \\
\text { and focused. Piece } \\
\text { contains some details }\end{array}$ & $\begin{array}{c}\text { Writing is confident and } \\
\text { clearly focused. It holds } \\
\text { the reader's attention. } \\
\text { Relevant details enrich } \\
\text { writing. }\end{array}$ \\
\hline Organization & $\begin{array}{c}\text { Writing is } \\
\text { disorganized and } \\
\text { underdeveloped with } \\
\text { no transitions or } \\
\text { closure. }\end{array}$ & $\begin{array}{c}\text { Writing is brief and } \\
\text { underdeveloped with } \\
\text { very weak transitions } \\
\text { and closure. }\end{array}$ & $\begin{array}{c}\text { Writing is confused and } \\
\text { loosely organized. } \\
\text { Transitions are weak and } \\
\text { closure is ineffective. }\end{array}$ & $\begin{array}{l}\text { Uses correct writing } \\
\text { format. Incorporates a } \\
\text { coherent closure. }\end{array}$ & $\begin{array}{l}\text { Writing includes a } \\
\text { strong beginning, } \\
\text { middle, and end, with } \\
\text { some transitions and } \\
\text { good closure. }\end{array}$ & $\begin{array}{c}\text { Writing includes a strong } \\
\text { beginning, middle, and } \\
\text { end, with clear } \\
\text { transitions and a } \\
\text { focused closure. }\end{array}$ \\
\hline $\begin{array}{c}\text { Vocabulary/Word } \\
\text { Choice }\end{array}$ & $\begin{array}{c}\text { Careless or } \\
\text { inaccurate word } \\
\text { choice, which } \\
\text { obscures meaning. }\end{array}$ & $\begin{array}{c}\text { Language is trite, } \\
\text { vague, or flat. }\end{array}$ & $\begin{array}{c}\text { Shows some use of varied } \\
\text { word choice. }\end{array}$ & $\begin{array}{c}\text { Uses a variety of word } \\
\text { choices to make writing } \\
\text { interesting. }\end{array}$ & $\begin{array}{c}\text { Purposeful use of word } \\
\text { choice. }\end{array}$ & $\begin{array}{c}\text { Effective and engaging } \\
\text { use of word choice. }\end{array}$ \\
\hline Voice & $\begin{array}{c}\text { Writer's voice/point } \\
\text { of view shows no } \\
\text { sense of audience. }\end{array}$ & $\begin{array}{c}\text { Writer's voice/point of } \\
\text { view shows little sense } \\
\text { of audience. }\end{array}$ & $\begin{array}{c}\text { Writer's voice/point of } \\
\text { view shows a vague sense } \\
\text { of audience. }\end{array}$ & $\begin{array}{l}\text { Writer uses voice/point } \\
\text { of view. Writes with an } \\
\text { understanding of a } \\
\text { specific audience. }\end{array}$ & $\begin{array}{l}\text { Writer has strong } \\
\text { voice/point of view. } \\
\text { Writing engages the } \\
\text { audience. }\end{array}$ & $\begin{array}{c}\text { Writes with a distinct, } \\
\text { unique voice/point of } \\
\text { view. Writing is skillfully } \\
\text { adapted to the audience. }\end{array}$ \\
\hline Sentence Fluency & $\begin{array}{l}\text { Frequent run-ons or } \\
\text { fragments, with no } \\
\text { variety in sentence } \\
\text { structure. }\end{array}$ & $\begin{array}{l}\text { Many run-ons or } \\
\text { frangments. Little } \\
\text { variety in sentence } \\
\text { structure. }\end{array}$ & $\begin{array}{c}\text { Some run-ons or } \\
\text { fragments. Limited variety } \\
\text { in sentence structure. }\end{array}$ & $\begin{array}{l}\text { Uses simple, compound, } \\
\text { and complex sentences. }\end{array}$ & $\begin{array}{l}\text { Frequently varied } \\
\text { sentence structure. }\end{array}$ & $\begin{array}{l}\text { Consistent variety of } \\
\text { sentence structure } \\
\text { throughout. }\end{array}$ \\
\hline Conventions & $\begin{array}{l}\text { Parts of speech show } \\
\text { lack of agreement. } \\
\text { Frequent errors in } \\
\text { mechanics. Little or } \\
\text { no evidence of } \\
\text { spelling strategies }\end{array}$ & \begin{tabular}{|} 
Inconsistent \\
agreement between \\
parts of speech. Many \\
errors in mechanics. \\
Little evidence of \\
spelling strategies.
\end{tabular} & $\begin{array}{c}\text { Occasional errors in } \\
\text { agreement between parts } \\
\text { of speech. Some errors in } \\
\text { mechanics. Some evidence } \\
\text { of spelling strategies. }\end{array}$ & $\begin{array}{c}\text { Maintains agreement } \\
\text { between parts of speech, } \\
\text { Few errors in mechanics. } \\
\text { Applies basic grade-level } \\
\text { spelling }\end{array}$ & $\begin{array}{l}\text { Consistent agreement } \\
\text { between parts of } \\
\text { speech. Uses correct } \\
\text { punctuation, } \\
\text { capitalization, and so } \\
\text { on. Consistent use of } \\
\text { spelling strategies. }\end{array}$ & $\begin{array}{c}\text { Uses consistent } \\
\text { agreement between parts } \\
\text { of speech. No errors in } \\
\text { mechanics. Creative and } \\
\text { effective use of spelling } \\
\text { strategies. }\end{array}$ \\
\hline $\begin{array}{c}\text { This rubric is } \\
\text { provided by } \\
\text { ReadWriteThing.org }\end{array}$ & & & & & & \\
\hline
\end{tabular}

